\title{
A POLÊMICA ABERTA DE O BOTICÁRIO: ANÁLISE BAKHTINIANA DE UM COMERCIAL PARA O DIA DOS NAMORADOS
}

\section{Anderson Cristiano da Silva ${ }^{1}$}

Resumo: Este trabalho analisa um comercial veiculado na televisão aberta referente a uma campanha para o dia dos namorados 2015, da empresa O Boticário. Justifica-se a pertinência da investigação pelas opiniões antagônicas que as imagens despertaram nos espectadores, uma vez que trouxe em sua narrativa uma noção de casal mais ampla, abarcando o público homossexual, o que despertou uma polêmica nas redes sociais e em outras mídias, gerando um debate a respeito da temática. Como aporte teórico, recorremos aos trabalhos desenvolvidos por Bakhtin e o Círculo, no qual elencamos o enunciado concreto como conceito-chave em nossas análises. Em nossas considerações, desconstruindo as caricaturas e estereótipos que geralmente são mostradas na mídia em tom de deboche e comédia, a empresa de cosmético optou por tratar o relacionamento entre pessoas do mesmo sexo de maneira sutil, mostrando o cotidiano comum de diferentes composições de casais.

Palavras-chave: Comercial; Polêmica aberta; Análise dialógica do discurso.

\footnotetext{
1 Pontifícia Universidade Católica de São Paulo/ Programa de Pós-Graduados em Linguística Aplicada e Estudos da Linguagem (LAEL), Rua Monte Alegre, 984, Perdizes, São Paulo-SP, Brasil. E-mail: andcs23@hotmail.com.
} 